\title{
The Influence of Discipline, Speed and Responsiveness of Office boy Work on Work Productivity at PT. Astra International Tbk, Bengkulu Branch
}

\section{Pengaruh Disiplin, Kecepatan dan Ketanggapan Kerja Office Boy Terhadap Produktivitas Kerja pada PT. Astra International,Tbk. Cabang Bengkulu}

\author{
Meylinda 1); Tezar Arianto2) \\ 1)Study Program of Management Faculty of Economic, Universitas Muhammadiyah Bengkulu \\ ${ }^{2)}$ Department of Management, Faculty of Economic, Universitas Muhammadiyah Bengkulu \\ Email: 2) tezar.arianto7@gmail.com
}

How to Cite:

Meylinda., Arianto, T. (2022). The Influence of Discipline, Speed and Responsiveness of Office boy Work on Work Productivity at PT. Astra International Tbk, Bengkulu Branch. Jurnal Ekonomi Manajemen Akuntansi Dan Keuangan, 3(1). DOI: https://doi.org/10.53697/emak.v3i1

ARTICLE HISTORY

Received [30 Desember 2021]

Revised [07 Januari 2022]

Accepted [27 Januari 2022]

\section{KEYWORDS}

Discipline, Speed,

Responsiveness, and Work

Productivity

This is an open access article under the $C C-B Y$-SA license

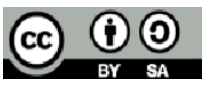

\section{ABSTRAK}

Penelitian ini bertujuan untuk mengetahui Pengaruh Disiplin, Kecepatan dan Ketanggapan Kerja Office boy terhadap Produktivitas Kerja di PT. Astra International, Tbk. Cabang Bengkulu, baik secara parsial maupun simultan. Responden dalam penelitian ini adalah Karyawan di PT. Astra International, Tbk. Cabang Bengkulu yang berjumlah 68 orang. Dalam penenlitian ini penulis menggunakan metode pengumpulan data dengan cara observasi, penyebaran angket atau kuisioner. Teknik analisis data yang digunakan dalam penelitian ini, menggunakan uji instrument, uji asumsi klasik, analisis tanggapan responden, analisis regresi linier berganda, koefisien determinan, dan juga uji hipotesis. Sehingga dapat disimpulkan bahwa Disiplin, Kecepatan dan Ketanggapan Kerja Office boy berpengaruh positif dan signifikan secara parsial maupun simultan terhadap Produktivitas Kerja di PT. Astra International, Tbk. Cabang Bengkulu..

\section{ABSTRACT}

This study aims to determine the Effect of Discipline, Speed, and Responsiveness of Work Office Boys on Work Productivity at PT. Astra International, Tbk. Bengkulu Branch, either partially or simultaneously. Respondents in this study were employees at PT. Astra International, Tbk. Bengkulu branch, totaling 68 people. In this research, the writer uses the method of collecting data by means of observation, distributing questionnaires, or questionnaires. Data analysis techniques used in this study, using instrument test, classical assumption test, analysis of respondents' responses, multiple linear regression analysis, determinant coefficients, and also hypothesis testing. So it can be concluded that the Discipline, Speed and Responsiveness of Work Office boy have a positive and significant effect partially or simultaneously on Work Productivity at PT. Astra International, Tbk. Bengkulu Branch. 


\section{PENDAHULUAN}

Perusahaan itu sendiri merupakan suatu organisasi yang menghimpun orang-orang yang disebut dengan karyawan atau pegawai untuk menjalankan aktivitas usaha di dalam perusahaan tersebut. Didalam sebuah perusahaan mempunyai tujuan yaitu memaksimalkan keuntungan dan nilai bagi perusahaan dan juga untuk meningkatkan kersejahteraan pemilik perusahaan, yang berkaitan dengan perusahaan dan karyawan. Keberhasilan perusahaan ditentukan oleh sumber daya manusia, karena tanpa adanya sumber daya manusia maka perusahaan tidak dapat meraih tujuan perusahaan. Sumber daya manusia yang baik dan optimal akan secara langsung berdampak pada kesuksesan perusahaan dalam meraih tujuan perusahaan. Perusahaan yang sukses tidak sekedar memberikan tugas kepada karyawan, tetapi juga memperhatikan apa yang dibutuhkan karyawan sehingga karyawan dapat dengan nyaman untuk bekerja. Sumber daya manusia yang telah terpenuhi kebutuhannya, secara otomatis karyawan akan memberikan lebih dari yang diharapkan oleh perusahaan sehingga produktivitas dari karyawan juga dinilai sangat baik oleh perusahaan.

Berdasarkan hasil wawancara dengan Ibu Dina sebagai salah satu karyawan PT. Astra International, Tbk Cabang Bengkulu dimana permasalahan yang terjadi yaitu produktivitas kerja office boy yang masih sangat kurang hal ini ditandai dengan cara kerjanya yang terkesan lamban, tidak cekapan, kurang bersih ketika menyapu dan hal ini disebabkan oleh sumber daya yang kurang berkompeten. Faktor utama yang menjadi penyebabnya adalah pendidikan office boy yang yang rendah, biasanya walaupun bagian office boy perusahaan merekrut karyawan berdasarkan latar belakang pendidikan yang jelas namun kenyataannya pada PT. Astra International, Tbk Cabang Bengkulu tidak melihat dari latar belakang pendidikan tersebut. Karena menurut PT. Astra International, Tbk Cabang Bengkulu pendidikan bukan salah satu faktor penting yang mendukung perusahaan ini agar tetap bertahan. Sehingga ketika bekerja office boy sulit diarahkan, sering atang terlambat, dan tidak tanggap ketika diperintahkan mengerjakan sesuatu.

\section{LANDASAN TEORI}

\section{Produktivitas Kerja}

Produktivitas kerja diartikan sebagai hasil pengukuran suatu kinerja dengan memperhitungkan sumber daya yang digunakan, termasuk sumber daya manusia menurut Schermerharn (2003), selanjutnya Hasibuan (2003) mengemukakan bahwa produktivitas adalah perbandingan antara output (hasil) dengan input (masukan). Jika produktivitas naik hal ini hanya dimungkinkan oleh adanya peningkatan efisiensi (waktu, bahan, tenaga) dan sistem kerja, teknis produksi dan adanya peningkatan keterampilan dari tenaga kerjanya. Menggunakan kemampuan atau mewujudkan segenap potensi guna mewujudkan kreativitas.

Indikator produktivitas menurut Hasibuan (2009) merupakan perbandingan antara output (hasil) dengan input (masukan), yaitu sebagai berikut :

1. Perbaikan terus menerus, yaitu upaya peningkatan produktifitas kerja salah satu implementasinya ialah bahwa seluruh komponen harus melakukan perbaikan secara terus menerus.

2. Peningkatan hasil mutu pekerjaan. Peningkatan hasil mutu pekerjaan dilaksanakan oleh semua komponen dalam organisasi.

3. Pemberdayaan sumber daya manusia. Memberdayakan sumber daya manusia mengandung kiat untuk : (a) mengakui harkat dan martabat manusia sebagai makhluk yang mulia, mempunyai harga diri, daya nalar, memiliki kebebasan memilih, akal, perasaan dan berbagai kebutuhan yang beraneka ragam; (b)manusia memiliki hak-hak asasi dan tidak ada manusia lain(manajemen) yangdibenarkan melanggar hak tesebut; (c) penerapan gaya manajemen yang partisipatif melalui proses berdemokrasi dalam kehidupan berorganisasi. 
4. Kondisi fisik tempat bekerja yang menyenangkan. Kondisi fisik tempat yang menyenangkan memberikan kontribusi yang nyata dalam peningkatan produktivitas kerja.

5. Umpan balik. Pelaksanaan tugas dan karier karyawan tidak dapat dipisahkan dari penciptaan, pemeliharaan, dan penerapan sistem umpan balik yang objektif, rasional, baku, dan validitas yang tinggi.

\section{Disiplin}

Disiplin adalah prosedur yang mengoreksi atau menghukum bawahan karena melanggar peraturan atau prosedur. Disiplin merupakan bentuk pengendalian diri pegawai dan pelaksanaan yang teratur dan menunjukan tingkat kesungguhan tim kerja di dalam organisasi, Menurutu, Simamora (2007). Menurut Moenir (2002) disiplin adalah suatu bentuk ketaatan terhadap aturan, baik tertulis maupun tidak tertulis yang telah ditetapkan. Disiplin merupakan bentuk Disiplin yang menegakkan peraturan-peraturan perusahaan, yang sering kali dipengaruhi oleh sistem disiplin di dalam perusahaan adalah para pegawai yang bermasalah. Jika perusahaan gagal menghadapi pegawai bermasalah, efek negatif kepada para pegawai lainnya dan kelompok kerja lainnya akan timbul, Mathis (2002).

Indikator disiplin menurut Hasibuan (2003) dapat diukur melalui berikut:

1. Kehadiran

Seseorang yang dijadwalkan untuk bekerja harus datang atau hadir pada waktunya tanpa alasan apapun.

2. Waktu kerja

Waktu kerja sebagai jangka waktu saat pekerja yang bersangkutan harus hadir untuk memulai pekerjaan dan ia dapat meninggalkan pekerjaan, dikurangi waktu istirahat antar permulaan dan akhir kerja. Mencetak jam kerja pada waktu hadir merupakan sumber data untuk mengetahui tingkat disiplin waktu kerja karyawan.

3. Kepatuhan terhadap perintah

Kepatuhan terjadi jika seseorang melakukan apa yang dikatakan kepadanya.

4. Kepatuhan terhadap peraturan

Serangkaian aturan-aturan yang dimiliki kelompok dalam organisasi, boleh jadi merupakan tekanan bagi seseorang atau karyawan agar patuh yang akan membentuk keyakinan, sikap dan perilaku individu tersebut menurut standar kelompok yang ada dalam suatu organisasi.

5. Pemakaian seragam

Setiap karyawan terutama di lingkungan organisasi menerima seragam kerja setiap dua tahun sekali.

\section{Kecepatan Kerja}

Kecepatan seseorang dalam melakukan suatu pekerjaan sangat penting bagi suatu perusahaan. Kecepatan juga dapat diartikan sebagai sikap seseorang dalam menyelesaikan suatu pekerjaan yang diukur dari cepat dan akuratnya pekerjaan tersebut. Kecepatan adalah suatu target waktu pelayanan yang dapat diselesaikan dalam waktu yang telah ditentukan oleh unit penyelenggara pelayanan menurut, Rahmayanty, (2010). Kecepatan dari setiap sub bagian atau bidang dalam suatu perusahaan baik perusahaan milik negara maupun swasta berpengaruh pada tingkat kepercayaan masyarakat terhadap suatu produk maupun jasa yang diberikan oleh perusahaan tersebut.

Kecepatan yang dilakukan oleh seseorang dalam melakukan pekerjaan melakukan pekerjaan dapat dilihat dari beberapa cara ataupun aspek Prawirosentono (2008) mengemukakan beberapa cara untuk mengukur kecepatan seseorang dalam bekerja, antara lain sebagai berikut: 
1. Waktu dalam pengerjaan. Waktu pengerjaan yang sesuai dengan tingkat kesulitan suatu pekerjaan menjadi salah satu tolok ukur dalam kecepatan.

2. Lama waktu tunggu pekerjaan. Waktu tunggu yang sesuai dengan tingkat kesulitan pekerjaan menjadi salah satu tolok ukur dalam kecepatan.

3. Sikap karyawan dalam bekerja. Sikap karyawan yang cekatan dalam bekerja dijadikan sebagai tolok ukur kecepatan pelayanan.

\section{Ketanggapan Kerja}

Ketanggapan (Responsiveness) adalah kemauan karyawan perusahaan (organisasi) yang tanggap dan bersedia membantu kepentingan pelanggan yang memerlukan layanan. Zeithan et.al (Umar; 2005) mengatakan Responsiveness, yaitu respons atau kesigapan karyawan dalam membantu pelanggan atau memberikan pelayanan yang cepat dan tanggap, yang meliputi kesigapan karyawan dalam melayani pelanggan, kecepatan karyawan dalam menangani transaksi dan menangani keluhan pelanggan.

Indikator daya tanggap menurut Aritonang (2005) meliputi:

1. Memberi layanan dengan cepat

2. Memberi layanan dengan cara yang tepat

3. Selalu siap sedia memberi bantuan

\section{METODE PENELITIAN}

\section{Metode Analisis}

Analisis yang digunakan dalam penelitian ini adalah analisis regresi berganda bertujuan untuk memprediksi berapa besar kekuatan pengaruh variabel independen terhadap variabel dependen. Persamaan regresinya adalah Sugiyono (2013):

Di mana:

$$
Y=b_{1} X_{1}+b_{2} X_{2}+b_{3} X_{3}+e
$$

Y : Produktivitas Kerja

b : Koefisien arah regresi

$\mathrm{X}_{1} \quad$ : Disiplin

$\mathrm{X}_{2} \quad$ : Kecepatan

$\mathrm{X}_{3} \quad$ : Ketanggapan

e : error

HASIL DAN PEMBAHASAN

Tabel 1. Hasil Analisis Regresi Linear Berganda

Coefficients $^{a}$

\begin{tabular}{|c|c|c|c|}
\hline \multirow[b]{2}{*}{ Model } & \multicolumn{2}{|c|}{ Unstandardized Coefficients } & \multirow{2}{*}{$\begin{array}{c}\text { Standardized Coefficients } \\
\text { Beta }\end{array}$} \\
\hline & B & Std. Error & \\
\hline 1 & & & \\
\hline Disiplin & .193 & .062 & .246 \\
\hline Kecepatan & .512 & .199 & .362 \\
\hline Ketanggapan Kerja & .439 & .184 & .347 \\
\hline
\end{tabular}

a. Dependent Variable: Produktivitas Kerja 
Dari perhitungan hasil regresi di atas didapatkan persamaan regresinya adalah sebagai berikut : $Y=0.193\left(\mathrm{X}_{1}\right)+0.512\left(\mathrm{X}_{2}\right)+0.439\left(\mathrm{X}_{3}\right)$. Berdasarkan persamaan regresi di atas, maka dapat dijelaskan sebagai berikut :

1. Koefisien Regresi $X_{1}$, sebesar 0.193 mempunyai makna jika nilai variabel Disiplin $\left(X_{1}\right)$ naik satu satuan maka nilai Produktivitas Kerja $(Y)$ akan naik sebesar 0.193 dengan asumsi variabel Kecepatan $\left(\mathrm{X}_{2}\right)$, Dan Ketanggapan $\left(\mathrm{X}_{3}\right)$ dianggap tetap.

2. Koefisien Regresi $X_{2}$, sebesar 0.512 mempunyai makna jika nilai variabel Kecepatan $\left(X_{2}\right)$ naik satu satuan maka nilai Produktivitas Kerja $(Y)$ akan naik sebesar 0.512 dengan asumsi variabel Disiplin $\left(\mathrm{X}_{1}\right)$ Dan Ketanggapan $\left(\mathrm{X}_{3}\right)$ dianggap tetap.

3. Koefisien Regresi $X_{3}$, sebesar 0.439 mempunyai makna jika nilai variabel Ketanggapan $\left(X_{3}\right)$ naik satu satuan maka nilai Produktivitas Kerja $(Y)$ akan naik sebesar 0.439 dengan asumsi variabel Disiplin $\left(\mathrm{X}_{1}\right)$ dan Kecepatan $\left(\mathrm{X}_{2}\right)$ dianggap tetap.

\section{Pembahasan}

Berdasarkan hasil penelitian dan pengolahan data yang dilakukan pada, Karyawan di PT. Astra International Tbk, Cabang Bengkulu melalui penyebaran kuesoner terhadap 68 orang responden yang telah diuji sehingga dapat diketahui pengaruh variabel bebas Disiplin $\left(\mathrm{X}_{1}\right)$, Kecepatan $\left(\mathrm{X}_{2}\right)$, Dan Ketanggapan $\left(\mathrm{X}_{3}\right)$ terhadap Produktivitas Kerja $(\mathrm{Y})$ di PT. Astra International Tbk, Cabang Bengkulu, Sehingga dapat diperoleh hasil sebagai berikut:

\section{Pengaruh Disiplin $\left(\mathrm{X}_{1}\right)$ Terhadap Produktivitas Kerja $(\mathrm{Y})$}

Hasil penelitian ini menunjukkan bahwa Disiplin memiliki pengaruh yang positif dan signifikan terhadap Produktivitas Kerja di PT. Astra International Tbk, Cabang Bengkulu. Hasil uji t membuktikan bahwa Disiplin memiliki nilai thitung $>t_{\text {tabel }}(3.090>1.99773)$ dan $(\operatorname{sig}<\alpha=0,003<$ $0,050)$, hal tersebut menyatakan adanya pengaruh Disiplin $\left(X_{1}\right)$ secara positif dan signifikan terhadap Produktivitas Kerja (Y) di PT. Astra International Tbk, Cabang Bengkulu. Artinya bahwa semakin disiplin seorang officeboy maka akan semakin meningkat pula Produktivitas Kerjanya.

Hasil ini diperkuat oleh teori dari Simamora, (2007) yang mengemukakan bahwa disiplin merupakan bentuk pengendalian diri pegawai dan pelaksanaan yang teratur dan menunjukan tingkat kesungguhan tim kerja di dalam organisasi. Menurut Moenir (2002), disiplin adalah suatu bentuk ketaatan terhadap aturan, baik tertulis maupun tidak tertulis yang telah ditetapkan. Disiplin harus ditumbuh kembangkan agar tumbuh pula ketertiban dan efisiensi. Selanjutnya menurut Rahmatullah (2003), disiplin haruslah dimiliki oleh setiap pegawai dan harus terus ditingkatkan.

Hal ini sejalan dengan penelitian yang dilakukan oleh Hermanto (2016) Pengaruh Kejelasan pelayanan, Kedisiplinan Petugas pelayanan dan infrastruktur Terhadap Produktivitas Kerja. Rizky, dkk. (2020). Dalam penelitian "Pengarub Disiplin Kerja dan ketanggapan Terhadap Produktivitas Kerja Karyawan Pizza Hut Wilayah Jakarta Timur. Toni Prayogo dan Ismiyati. 2018. Dengan judul "Pengaruh ketanggapan dan disiplin kerja terhadap Produktivitas Kerja. Dimana hasil dari ketiga penelitian tersebut menyatakan bahwa kedisiplinan memiliki pengaruh yang positif dan signifikan terhadap Produktivitas Kerja. Hasil penelitian dari Prasetyo, Marlina (2019). Pengaruh Disiplin Kerja dan Kepuasan Kerja Terhadap Produktivitas Kerja.

\section{Pengaruh Kecepatan $\left(\mathrm{X}_{2}\right)$ Terhadap Produktivitas Kerja $(\mathrm{Y})$}

Hasil penelitian ini menunjukkan bahwa Kecepatan memiliki pengaruh yang positif dan signifikan terhadap Produktivitas Kerja di PT. Astra International Tbk, Cabang Bengkulu. Hasil uji t membuktikan bahwa Disiplin memiliki nilai thitung $>t_{\text {tabel }}(2.573>1.99773)$ dan $(\operatorname{sig}<\alpha=0,012<$ $0,050)$, hal tersebut menyatakan adanya pengaruh Kecepatan $\left(X_{2}\right)$ secara positif dan signifikan terhadap Produktivitas Kerja (Y) di PT. Astra International Tbk, Cabang Bengkulu. Kecepatan dalam bekerja harus diimbangi pula dengan hasil kerja yang baik, seperti kebersihan maupun kerapiannya. 
Hasil penelitian ini diperkuat oleh peneletian terdahulu Rahmayanty, (2010) yang mengemukakan bahwa kecepatan adalah suatu target waktu pelayanan yang dapat diselesaikan dalam waktu yang telah ditentukan oleh unit penyelenggara pelayanan. Kecepatan dari setiap sub bagian atau bidang dalam suatu perusahaan baik perusahaan milik negara maupun swasta berpengaruh pada tingkat kepercayaan masyarakat terhadap suatu produk maupun jasa yang diberikan oleh perusahaan tersebut. Bangun (2012) mengemukakan bahwa salah satu faktor yang mempengaruhi kepuasan pelanggan adalah kecepatan. Sadarmayanti (2014). Kecepatan seseorang dalam melakukan suatu pekerjaan sangat penting bagi suatu perusahaan. Kata kecepatan berasal dari kata cepat yang berarti dalam waktu singkat atau segera atau lekas, sedangkan kecepatan sendiri diartikan terlampau cepat ataupun terdahulu. Kecepatan juga dapat diartikan sebagai sesuatu yang dilakukan dengan waktu yang singkat.

Hal ini sejalan dengan penelitian yang dilakukan oleh (2015). Dalam penelitian yang berjudul "Hubungan Kecepatan waktu pelayanan terhadap Produktivitas. Zaini Mohammad, 2019. Dengan judul "Analisis Faktor Kecepatan Bongkar Muat, Fasilitas peralatan, keamanan kerja dan kinerja pegawai terhadap Produktivitas kerja di PT. Terminal Petikemas Semarang". Agus (2013) Pengaruh Kedisiplinan Dan Ketanggapan Terhadap Produktivitas kerja Pada Hotel Di Kabupaten Semarang. Hasil dari ketiga penelitian di atas menyatakan bahwa kecepatan memiliki pengaruh yang positif dan signifikan terhadap Produktivitas kerja.

\section{Pengaruh Ketanggapan $\left(X_{3}\right)$ Terhadap Produktivitas Kerja $(Y)$}

Hasil penelitian ini menunjukkan bahwa ketanggapan memiliki pengaruh yang positif dan signifikan terhadap Produktivitas Kerja di PT. Astra International Tbk, Cabang Bengkulu. Karyawan yang tanggap akan situasi kerja dan responsive terhadap para karyawan lainnya merupakan sebuah hal yang harus dimiliki. Hasil uji t membuktikan bahwa Ketanggapan kerja memiliki nilai $t_{\text {hitung }}>t_{\text {tabel }}$ $(2.385>1.9884)$ dan (sig $<\alpha=0,020<0,050$ ), hal tersebut menyatakan adanya pengaruh Ketanggapan $\left(\mathrm{X}_{3}\right)$ secara positif dan signifikan terhadap Produktivitas Kerja (Y) di PT. Astra International Tbk, Cabang Bengkulu. Agar kedepannya Produktivitas Kerja para officeboy meningkat mereka harus lebih sigap dan tanggap lagi dalam bekerja.

Hasil ini didukung oleh teori dari Lenvinne (2005), Ketanggapan (Responsiveness) ini mengukur daya tanggap provides terhadap harapan, keinginan dan aspirasi serta tuntutan coustomer. Husain Umar (2005), Ketanggapan yaitu respons atau kesigapan karyawan dalam membantu pelanggan atau memberikan pelayanan yang cepat dan tanggap, yang meliputi kesigapan karyawan dalam melayani pelanggan, kecepatan karyawan dalam menangani transaksi dan menangani keluhan pelanggan.

Hal ini sejalan dengan penelitian yang dilakukan oleh Raharjo (2013) Pengaruh Keandalan, Bukti Langsung, Daya Tanggap (kecepatan), Jaminan, Dan Empati Terhadap Produktivitas Kerja Anggota Koperasi Pegawai Republik Indonesia (Kpri) "Aneka Usaha" Pusat Veterinaria Farma. Pratama Rizky, dkk (2020). Dalam penelitian "Pengarub Disiplin Kerja dan Ketanggapan Terhadap Produktivitas Kerja Pizza Hut Wilayah Jakarta Timur. Prayogo dan Ismiyati (2018) Dengan judul "Pengaruh ketanggapan dan disiplin kerja terhadap Produktivitas Kerja. Dimana hasil dari ketiga penelitian tersebut menyatakan bahwa ketanggapan memiliki pengaruh yang positif dan signifikan terhadap Produktivitas Kerja.

\section{Pengaruh Disiplin, Kecepatan dan Ketanggapan Kerja Terhadap Produktivitas Kerja (Y)}

Hasil penelitian ini menunjukkan bahwa Disiplin, Kecepatan dan Ketanggapan memiliki pengaruh yang positif dan signifikan terhadap Produktivitas Kerja (Y) di PT. Astra International Tbk, Cabang Bengkulu. Hal ini sejalan dengan penelitian yang dilakukan oleh Raharjo (2013) Pengaruh Keandalan, Bukti Langsung, Daya Tanggap (kecepatan), Jaminan, Dan Empati Terhadap Produktivitas Kerja Anggota Koperasi Pegawai Republik Indonesia (Kpri) "Aneka Usaha" Pusat Veterinaria Farma. Hal ini sejalan dengan penelitian yang dilakukan oleh Jannah, (2015). Dalam penelitian yang berjudul "Hubungan Kecepatan waktu pelayanan terhadap Produktivitas Kerja. 
Mohammad, (2019). Dengan judul "Analisis Faktor Kecepatan Bongkar Muat, Fasilitas peralatan, keamanan kerja dan kinerja pegawai terhadap Produktivitas Kerja di PT. Terminal Petikemas Semarang".

\section{KESIMPULAN DAN SARAN}

\section{Kesimpulan}

Hasil penelitian yang telah dilakukan tentang Pengaruh Disiplin, Kecepatan dan Ketanggapan Kerja Officeboy terhadap Produktivitas Kerja (Y) di PT. Astra International Tbk, Cabang Bengkulu, maka diperoleh bahwa; disiplin memiliki pengaruh positif dan signifikan terhadap produktivitas kerja di PT. Astra International Tbk, Cabang Bengkulu. Selanjutnya pada kecepatan memiliki pengaruh positif dan signifikan terhadap produktivitas kerja di PT. Astra International Tbk, Cabang Bengkulu. Begitu juga pada ketanggapan kerja memiliki pengaruh positif dan signifikan terhadap produktivitas kerja di PT. Astra International Tbk, Cabang Bengkulu. Serta disiplin, kecepatan dan ketanggapan Kerja secara simultan atau bersama-sama memiliki pengaruh positif dan signifikan Terhadap produktivitas kerja di PT. Astra International Tbk, Cabang Bengkulu.

\section{Saran}

1. Pada Variabel Disiplin (X1), Disarankan pada pihak perusahaan untuk berani lebih tegas lagi dalam memberikan peringatan pada mereka yang tidak patuh pada peraturan maupun perintah dari atasan, sehingga kedepannya bisa jauh lebih baik lagi.

2. Pada Variabel Kecepatan (X2), Disarankan pada pihak perusahaan untuk berkoordinasi dengan pihak ketiga terkait dengan officeboy yang ada di PT. Astra ini, supaya pihak penyedia jasa office boy bisa memberikan peringatan terhadap para karyawannya untuk dapat lebih patuh dan bersikap dengan baik.

3. Pada Variabel Ketanggapan (X3), Disarankan pada pihak perusahaan untuk kedepannya apabila masih sering terjadi kesalahan-kesalahan yang serupa, lebih baik mencari tenaga officeboy yang lain, yang bisa diatur dan bisa bekerja dengan baik.

4. Pada Variabel Produktivitas Kerja (Y), Disarankan pada pihak perusahaan untuk dapat lebih tegas lagi dalam memberikan arahan serta standar hasil kerja yang harus dilakukan oleh para office boy.

\section{DAFTAR PUSTAKA}

Aritonang Lerbin R. (2005). Kepuasan Pelanggan. Jakarta: PT Gramedia Pustaka. Utama Agus. (2013). Pengaruh Disiplin Dan Ketanggapan Terhadap Kepuasan Pelanggan Dengan Kualitas Pelayanan Sebagai Variabel Intervening (Studi Pada Hotel Di Kabupaten Semarang)

Fika. (2015). Pengaruh disiplin kerja, kepuasan kerja, dan gaya kepemimpinan terhadap kinerja karyawan bagian produksi PT. Nyonya Meneer Semarang.

Hasibuan, (2003). Organisasi dan Motivasi Dasar Peningkatan Produktivitas. Jakarta: Bumi Aksara. Henry Simamora. (2007). Manajemen Sumber Daya Manusia. Yogyakarta: STIE YKPN.

Moenir. (2002). Maanajemen Pelayanan Umum di Indonesia. Jakarta: PT. Bumi. Aksara.

Nina Rahmayanty, (2010). Manajemen Pelayanan Prima. Yogyakarta : Graha. Ilmu.

Rahmatullah, (2003). Memahami Aspek-Aspek Pengelolaan Sumber Daya Manusia Dalam Organisasi. Jakarta: Grasindo.

Sugiyono. (2013). Metode Penelitian Kuantitatif, Kualitatif, dan R\&D. Bandung: CV. Alfabeta Wilson Bangun. (2012). Manajemen Sumber Daya Manusia. Jakarta: Erlangga. 